\title{
A systematic review of postgraduate training programmes directed at pharmacists entering primary care
}

\author{
Anna Groen ${ }^{1}$ (D) , Cherie Lucas $^{1}$ (D) , Helen Benson ${ }^{1}$ (D) , Mohammed Alsubaie ${ }^{2}$, Matthew J Boyd ${ }^{2}$ (iD \\ ${ }^{1}$ Graduate School of Health, Pharmacy, University of Technology Sydney, Sydney, Australia \\ ${ }^{2}$ School of Pharmacy, the Pharmacy Practice and Policy Division, University of Nottingham, Nottingham, United Kingdom
}

\author{
Keywords \\ Education \\ General Practice \\ Pharmacists \\ Primary Care \\ Training
}

\author{
Correspondence \\ Anna Groen \\ Graduate School of Health \\ Pharmacy \\ University of Technology Sydney \\ Sydney \\ Australia \\ anna.989@hotmail.com
}

\begin{abstract}
This systematic review explores the international postgraduate education and training programmes designed to provide or develop knowledge or skills focused on enabling pharmacists to work in a general practice setting. Four thousand, eight hundred and seventy-one $(4,871)$ articles were identified from database searches of SCOPUS, EMBASE, Medline, CINAHL, IPA, Web of Science and ERIC. After removal of duplicates and article screening, seven articles were included. Educational content, setting, contact time and methods of assessment varied across all studies. There is paucity of published literature relating to the development and evaluation of education programmes directed at pharmacists entering into general practice. A combination of work and classroom-based education provided by general practitioners and pharmacists already working in primary care is deemed most beneficial coupled with systematic debriefing sessions at the completion of training courses. The findings suggest future training should focus on specific disease states.
\end{abstract}

\section{Introduction}

Non-dispensing pharmacists are increasingly being integrated into primary healthcare settings as part of general practice (family medical centre) teams in countries such as the United Kingdom (UK) (Silcock, Raynor, \& Petty, 2004; Bush et al., 2018), Canada (Sellors et al., 2001; Dolovich et al., 2008), the United States of America (USA) (American Society of Health-System Pharmacists, 1999; Kozminski et al., 2011) and Australia (Benson et al., 2014; Freeman et al., 2014; Tan et al., 2014). Evidence supports the premise of embedding pharmacists in general practice environments to help minimise medication errors and relieve the increasing workload demand and time pressures faced by general practitioners (GPs) (Choe et al., 2012; Komwong et al.,
2018; Mann et al., 2018). Within this role pharmacists deliver professional services such as medication management reviews, provision of drug information, patient education and counselling, health promotion, conducting of specific disease management clinics, dose adjustments/prescribing and mentoring of new practice pharmacists (Tan et al., 2014).

Worldwide the educational and training requirements for registered pharmacists varies, including the total length of training towards attaining a qualifying degree which ranges from four to six years in most countries. Clinical training is conducted, either during the course of study or as a postgraduate internship or residency, generally for a duration of four months to one year (Global Knowledge Exchange Network, 2009). Most countries require licensure, 
certification or registration of pharmacy graduates through a national examination before entering practice, enabling pharmacists to perform at a general foundation level and practice within a broad scope (Global Knowledge Exchange Network, 2009; International Pharmaceutical Federation [FIP], 2015). Despite the extensive training pharmacists receive, they are under-utilised in their current position predominantly as medication dispensers (Mossialos et al., 2015). Given their training and expertise, they are in a suitable position to expand their scope of practice to help with the provision of healthcare within the general practice team (Mossialos et al., 2015; Stone \& William, 2015).

A report by the National Health Service (NHS) England posits that pharmacists require additional skill sets and training in order to perform more clinical roles in general practice, skill sets which are not adequately provided in current pharmacy education (Mills, 2018). These skill sets pertain to the following areas of training: clinical assessment, examination and monitoring; long-term condition management; common ailment management; leadership and management; understanding GP systems; independent prescribing and consultation skills (Farrell et al., 2008; Mills, 2018). While the general trend towards pharmacists practicing in more autonomous clinical patient focused roles has spurred reforms in pharmacy education and practice (FIP, 2009), a need has been deduced for the development of a credentialing process to assess and accredit potential practice pharmacists against validated competencies (Tan et al., 2014; FIP, 2015; Saseen et al., 2017).

Competency-based education is prevailing for the education of healthcare professionals (Bruno et al., 2010; Nash et al., 2015) with FIP noting that the capacity to improve therapeutic outcomes, patients' quality of life, scientific advancement and enhancement of our public health imperatives are dependent on the foundation of competence' (FIP, 2012a). Competency refers to the combination of skills, knowledge, behaviours, and attitudes that an individual develops through education, training, and experience (FIP, 2012a). As such, education programmes aimed at building the skills of pharmacists in primary care should be developed according to a competency framework.

With pharmacists entering into these roles in general practice there is little known about the education programmes facilitating this transition into practice. This systematic review aims to explore the postgraduate education and training programmes designed to provide or develop knowledge or skills focused on enabling pharmacists to work in a general practice setting.

\section{Methods}

This systematic review followed the Preferred Reporting Items for Systematic Reviews and Meta-Analysis (PRISMA) guidelines (Moher et al., 2009). A protocol was developed and published on PROSPERO under the registration number CRD42019117516 (Groen et al., 2017).

Research articles published in the English language without any other limitations placed on methodology or dates were deemed eligible for inclusion. Searches were conducted from the 7th November 2018 until the 28th December 2018. Studies were required to depict education and training interventions designed to provide or enhance knowledge or skills focused on enabling pharmacists to work in a general practice setting. Studies with undergraduate students or pharmacists practicing solely outside of general practice (e.g. community, hospital and pharmaceutical industry pharmacists) were excluded. Articles were not limited by study methodology.

\section{Table I: Scopus search strategy}

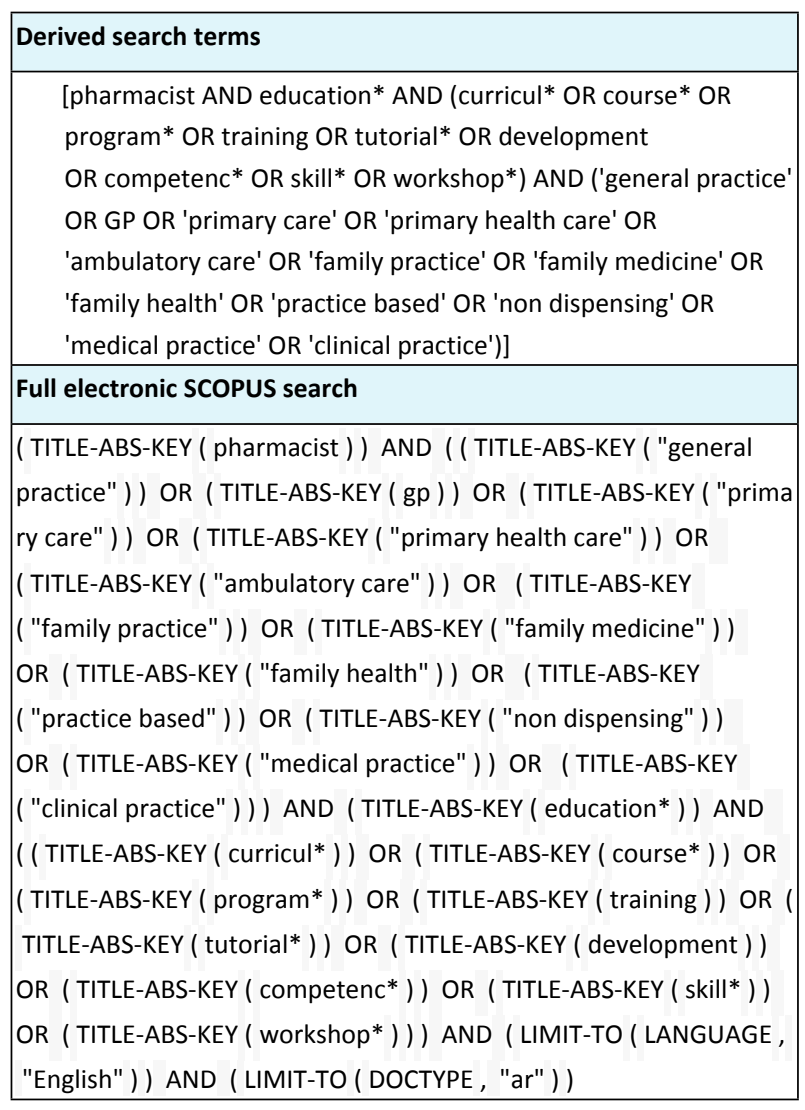

A search of the following electronic databases was conducted in December 2018: EMBASE, MEDLINE, Scopus, Web of Science, Cumulative Index of Nursing and Allied 
Health Literature (CINAHL), International Pharmaceutical Abstracts (IPA) and Education Resources Information Centre (ERIC). An experienced librarian (SY) assisted the lead author (AG) with the search strategy, which attained further consultation and general consensus by the research team (MB, CL and $\mathrm{HB}$ ). The search terms that were derived and used are outlined in Table $\mathrm{I}$ in conjunction with an example of the full electronic search query for SCOPUS. These same search terms were combined and adapted for use in each database.

Study titles and abstracts were screened for relevance and eligibility by the lead author (AG). The lead author and a second review author ( $A G$ and $M A$ ) then independently read the full text of remaining articles based on the inclusion and exclusion criteria. Any discrepancies regarding articles for inclusion were resolved through discussion with a third review author (MB).

The data on study characteristics were manually extracted by AG. These included the names of first author, year, country, data collection methods, participants, study objectives and key findings relating to education. Due to the broad nature of the research question and substantial heterogeneity between studies, a narrative synthesis was conducted as it employs words and text to summarise and explain the findings of the synthesis (Popay et al., 2009).

Figure A: PRISMA flow diagram of search strategy and study selection

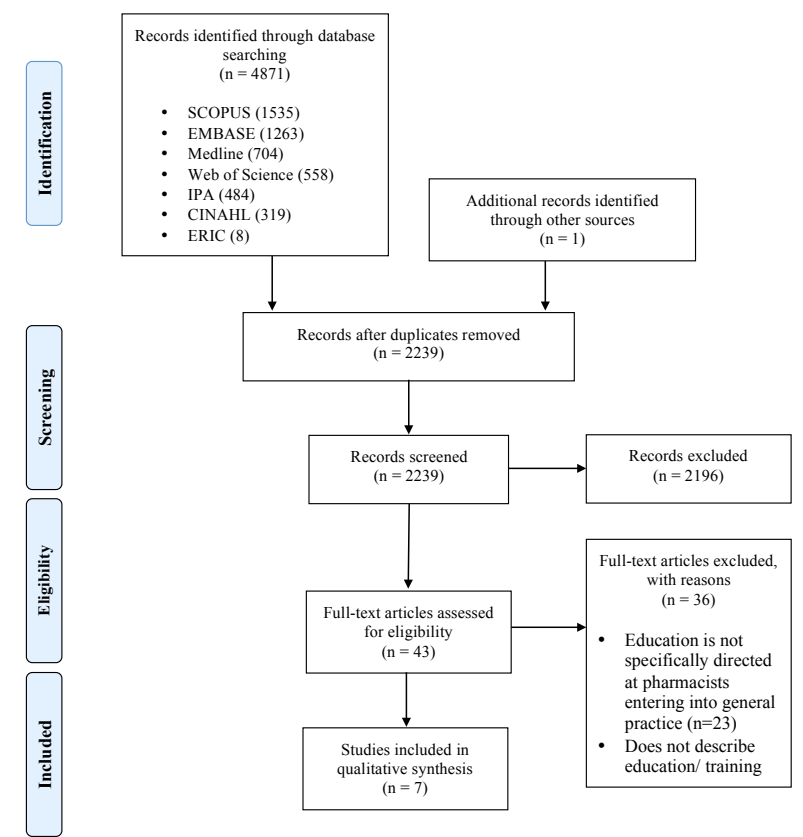

The Mixed Methods Appraisal Tool (MMAT) (Hong et al., 2018) is the only tool that has established validity and reliability, enabling critical appraisal of all research designs to facilitate the synthesis of qualitative and quantitative studies (Pluye et al., 2009; Pace et al., 2012; Souto et al., 2015). The MMAT allows for a description of the quality of studies from which the evidence is gathered hence all studies were include irrespective of their quality assessment. This tool comprises of two screening questions and five methodological quality criteria that are used depending on the study design and methods. The possible answers for each question are 'yes', 'no' and 'can't tell'. Using the MMAT, two researchers (AG and HB) independently appraised the quality of the included articles with any disagreements discussed until census was reached.

\section{Results}

A total of 4,871 articles were identified from the databases searched: SCOPUS ( $n=1535)$, EMBASE $(n=1263)$, Medline $(n=704)$, CINAHL $(n=319)$, IPA $(n=484)$, Web of Science $(n=558)$, and ERIC $(n=8)$. After duplicates were removed, articles were screened and assessed for eligibility, seven articles were identified and included in this systematic review (Jesson, Wilson, \& Blenkinsopp, 2001; Austin et al., 2005; Lau, Dolovich, \& Austin, 2007; Sadler et al., 2014; Butterworth et al., 2017; Hazen et al., 2018a; Hazen et al., 2018b). The PRISMA 2009 (Moher et al., 2009) flow diagram (Figure A) highlights the search and review processes.

The characteristics of the included studies are highlighted in Table II. All articles were published between 2001 to 2018 ( $n=7)$, with majority employing qualitative methods $(n=5)$. These studies were conducted in three countries including the UK (Jesson, Wilson, \& Blenkinsopp, 2001; Sadler et al., 2014; Butterworth et al., 2017), Canada (Austin et al., 2005; Lau, Dolovich, \& Austin, 2007) and the Netherlands (Hazen et al., 2018a; Hazen et al., 2018b) with four articles presenting different perspectives of two interventions (Austin et al., 2005; Lau, Dolovich, \& Austin, 2007; Hazen et al., 2018a; Hazen et al., 2018b). The majority of the studies were small consisting of less than 20 participants (Austin et al., 2005; Lau, Dolovich, \& Austin, 2007; Sadler et al., 2014 Butterworth et al., 2017; Hazen et al., 2018a; Hazen et al., 2018b), with the exception of one study that comprised of 116 participants (Jesson, Wilson, \& Blenkinsopp, 2001). 
Table II: Summary of studies

\begin{tabular}{|c|c|c|c|c|c|c|}
\hline Study & Country & Study objectives & $\begin{array}{l}\text { Data collection } \\
\text { methods }\end{array}$ & $\begin{array}{l}\text { Sample } \\
\text { size }\end{array}$ & Participants & Conclusions relating to education \\
\hline $\begin{array}{l}\text { Austin et al., } \\
2005\end{array}$ & Canada & $\begin{array}{l}\text { - To describe the } \\
\text { development of a } \\
\text { Family Practice } \\
\text { Simulator (FPS) }\end{array}$ & $\begin{array}{l}\text { Two surveys using } \\
\text { 7-point Likert scale: } \\
\text { - One immediately } \\
\text { upon completion } \\
\text { - One a month } \\
\text { following completion }\end{array}$ & $\mathrm{n}=9$ & $\begin{array}{l}\text { Pharmacists with no } \\
\text { previous experience in } \\
\text { primary care pharmacy } \\
\text { practice }\end{array}$ & $\begin{array}{l}\text { - The value of simulating a practice } \\
\text { style, location, and multiple types } \\
\text { of tasks are beneficial in training } \\
\text { pharmacists for more effective, } \\
\text { collaborative work with } \\
\text { physicians } \\
\text { - All participants supported } \\
\text { ongoing use of the FPS as an } \\
\text { educational intervention, } \\
\text { particularly for pharmacist } \\
\text { entering primary care }\end{array}$ \\
\hline $\begin{array}{l}\text { Butterworth } \\
\text { et al., } 2017\end{array}$ & $\begin{array}{l}\text { United } \\
\text { Kingdom }\end{array}$ & $\begin{array}{l}\text { - To explore } \\
\text { pharmacists' } \\
\text { perceptions of } \\
\text { primary care roles, } \\
\text { including the potential } \\
\text { for greater integration } \\
\text { of their profession } \\
\text { into general practice } \\
\text { and the future } \\
\text { potential of this role }\end{array}$ & $\begin{array}{l}\text { Semi-structured } \\
\text { phone interviews: } \\
\text { - One pre-course } \\
\text { - One post-course } \\
\end{array}$ & $n=16$ & $\begin{array}{l}\text { Pharmacists: } \\
\text { - Seven community } \\
\text { - Five clinical } \\
\text { commissioning group } \\
\text { (CCG) pharmacists } \\
\text { working in general } \\
\text { practice } \\
\text { - Four CCG } \\
\text { pharmacists not } \\
\text { directly working in } \\
\text { general practice } \\
\end{array}$ & $\begin{array}{l}\text { - There's enthusiasm and } \\
\text { willingness among pharmacists } \\
\text { for new, extended roles in } \\
\text { primary care } \\
\text { - A definition of the role, with } \\
\text { examples of the knowledge, skills, } \\
\text { and attributes required, should be } \\
\text { made available to pharmacists, } \\
\text { primary care teams, and the } \\
\text { public. } \\
\text { - Training should include clinical } \\
\text { skills teaching, set in context } \\
\text { through exposure to general } \\
\text { practice, and delivered } \\
\text { motivationally by primary care } \\
\text { providers }\end{array}$ \\
\hline $\begin{array}{l}\text { Hazen et al., } \\
2018 a\end{array}$ & $\begin{array}{l}\text { The } \\
\text { Netherlands }\end{array}$ & $\begin{array}{l}\text { - To unravel boundary } \\
\text { crossing as it relates } \\
\text { to professional } \\
\text { identity formation in } \\
\text { pharmacists } \\
\text { transitioning from a } \\
\text { community pharmacy } \\
\text { to working as } \\
\text { non-dispensing clinical } \\
\text { pharmacists in general } \\
\text { practice, with the aim } \\
\text { of optimising their } \\
\text { education }\end{array}$ & $\begin{array}{l}\text { - Semi structured } \\
\text { interviews: } \\
\text { - One within first } \\
\text { three months of } \\
\text { program, } \\
\text { - One a year after } \\
\text { completion } \\
\text { - Reports of weekly } \\
\text { peer feedback } \\
\text { sessions } \\
\text { - Three individual } \\
\text { reflective reports }\end{array}$ & $\mathrm{n}=10$ & $\begin{array}{l}\text { Pharmacists with no } \\
\text { previous experience in } \\
\text { primary care pharmacy } \\
\text { practice }\end{array}$ & $\begin{array}{l}\text { - Professional identity formation in } \\
\text { the transition from community } \\
\text { pharmacist to clinical pharmacist } \\
\text { in general practice benefited from } \\
\text { reflective, on-the-job training } \\
\text { - This permitted transformative, } \\
\text { boundary-crossing learning with } \\
\text { peers and supported professional } \\
\text { identity formation oriented to } \\
\text { providing practice-based } \\
\text { pharmaceutical care }\end{array}$ \\
\hline $\begin{array}{l}\text { Hazen et al., } \\
2018 b\end{array}$ & $\begin{array}{l}\text { The } \\
\text { Netherlands }\end{array}$ & $\begin{array}{l}\text { - To describe the design } \\
\text { of the training } \\
\text { programme } \\
\text { - To discuss some } \\
\text { general findings from } \\
\text { the evaluation of the } \\
\text { programme }\end{array}$ & $\begin{array}{l}\text { Two semi-structured } \\
\text { interviews: } \\
\text { - One within first } \\
\text { three months of } \\
\text { programme } \\
\text { - One a year after } \\
\text { completion }\end{array}$ & $n=10$ & $\begin{array}{l}\text { Pharmacists with no } \\
\text { previous experience in } \\
\text { primary care pharmacy } \\
\text { practice }\end{array}$ & $\begin{array}{l}\text { - Training provided increase } \\
\text { opportunities to clinical } \\
\text { pharmacists to add value in } \\
\text { general practice } \\
\text { - The training programme enabled } \\
\text { pharmacists to advance their skills } \\
\text { in direct patient care and to } \\
\text { improve the alignment between } \\
\text { different professionals in the } \\
\text { primary care domain }\end{array}$ \\
\hline $\begin{array}{l}\text { Jesson, } \\
\text { Wilson, \& } \\
\text { Blenkinsopp, } \\
2001\end{array}$ & $\begin{array}{l}\text { United } \\
\text { Kingdom }\end{array}$ & $\begin{array}{l}\text { - To map the tasks, } \\
\text { activities and training } \\
\text { provision for primary } \\
\text { care pharmacists } \\
\text { (PCPs) } \\
\text { - To identify perceived } \\
\text { future training needs }\end{array}$ & $\begin{array}{l}\text { - Self-completed postal } \\
\text { survey }\end{array}$ & $n=119$ & $\begin{array}{l}\text { Primary care } \\
\text { pharmacists }\end{array}$ & $\begin{array}{l}\text { - PCPs need further training or } \\
\text { updating to develop into the } \\
\text { wider role needed by the NHS. } \\
\text { PCPs may focus on technical } \\
\text { knowledge and information at the } \\
\text { expense of other competence } \\
\text { elements. } \\
\text { - Considerations needs to be given } \\
\text { to formal recognition of the } \\
\text { training of PCPs in order to assure } \\
\text { competence. } \\
\text { - The expectation that pharmacists } \\
\text { should fund their own training is } \\
\text { likely to be a barrier to uptake of } \\
\text { training and uncertainties over } \\
\text { funding will militate against } \\
\text { consistency of training. }\end{array}$ \\
\hline
\end{tabular}


Table II: Summary of studies (continued)

\begin{tabular}{|c|c|c|c|c|c|c|}
\hline Study & Country & Study objectives & $\begin{array}{l}\text { Data collection } \\
\text { methods }\end{array}$ & $\begin{array}{l}\text { Sample } \\
\text { size }\end{array}$ & Participants & Conclusions relating to education \\
\hline $\begin{array}{l}\text { Lau, Dolovich, } \\
\text { \& Austin, } \\
2007\end{array}$ & Canada & $\begin{array}{l}\text { - To compare } \\
\text { pharmacists' } \\
\text { performance ratings } \\
\text { from self, physician, } \\
\text { and standardised } \\
\text { patient evaluations } \\
\text { using Global Rating } \\
\text { Scales and } \\
\text { station-specific key } \\
\text { points checklists }\end{array}$ & $\begin{array}{l}\text { Evaluation using } \\
\text { 5-point Global Rating } \\
\text { Scales (GRS) }\end{array}$ & $\mathrm{n}=9$ & $\begin{array}{l}\text { Pharmacists with no } \\
\text { previous experience in } \\
\text { primary care pharmacy } \\
\text { practice }\end{array}$ & $\begin{array}{l}\text { - Low-moderate agreement in } \\
\text { rating scores between } \\
\text { pharmacists, standardised } \\
\text { patients, and physicians. } \\
\text { - FPS provided an important } \\
\text { opportunity to measure } \\
\text { expectations regarding the } \\
\text { professional role, responsibilities, } \\
\text { and performance if pharmacists } \\
\text { from a multi-professional } \\
\text { perspective, thus better preparing } \\
\text { pharmacists for integration into } \\
\text { primary care practice. }\end{array}$ \\
\hline $\begin{array}{l}\text { Sadler et al., } \\
2014\end{array}$ & $\begin{array}{l}\text { United } \\
\text { Kingdom }\end{array}$ & $\begin{array}{l}\text { - To describe the } \\
\text { training undertaken } \\
\text { by pharmacists } \\
\text { employed in a } \\
\text { pharmacist-led } \\
\text { information } \\
\text { technology-based } \\
\text { intervention study to } \\
\text { reduce medication } \\
\text { errors in primary care } \\
\text { - Evaluate pharmacists' } \\
\text { assessment of the } \\
\text { training, and the time } \\
\text { implications of } \\
\text { undertaking the } \\
\text { training }\end{array}$ & $\begin{array}{l}\text { - Self-rated } \\
\text { questionnaires } \\
\text { immediately after } \\
\text { training sessions } \\
\text { using 3-point Likert } \\
\text { scale (five in total) } \\
\text { - Reflective diary }\end{array}$ & $\mathrm{n}=6$ & $\begin{array}{l}\text { Pharmacists: } \\
\text { - Three experienced } \\
\text { within a general } \\
\text { practice setting } \\
\text { - Three without }\end{array}$ & $\begin{array}{l}\text { - The use of key principles of } \\
\text { education outreach and root } \\
\text { cause analysis resulted in } \\
\text { pharmacists feeling more } \\
\text { competent in delivering the } \\
\text { PINCER Trial intervention. } \\
\text { - Could have a wider application } \\
\text { helping pharmacists have a more } \\
\text { proactive day-to-day role in } \\
\text { helping GP practice identify key } \\
\text { system failure in relation to } \\
\text { prescribing safety and in turn } \\
\text { improve outcomes in a wide } \\
\text { range of pharmaceutical } \\
\text { interventions. } \\
\text { - These principles should be } \\
\text { incorporated into pharmacy } \\
\text { practice, particularly in the } \\
\text { primary care setting. Training } \\
\text { needs and provision of training } \\
\text { for pharmacists delivering } \\
\text { interventions in GP practices } \\
\text { should be thought about. }\end{array}$ \\
\hline
\end{tabular}

Table III: MMAT quality analysis

\begin{tabular}{|c|c|c|c|c|c|c|c|}
\hline Qualitative & $\begin{array}{l}\text { S1. Are } \\
\text { there clear } \\
\text { research } \\
\text { questions? }\end{array}$ & $\begin{array}{l}\text { S2. Do the } \\
\text { collected } \\
\text { data address } \\
\text { the research } \\
\text { questions? }\end{array}$ & $\begin{array}{l}\text { 1.1. Is the } \\
\text { qualitative } \\
\text { approach } \\
\text { appropriate to } \\
\text { answer the } \\
\text { research question? }\end{array}$ & $\begin{array}{l}\text { 1.2. Are the } \\
\text { qualitative data } \\
\text { collection methods } \\
\text { adequate to address } \\
\text { the research } \\
\text { question? }\end{array}$ & $\begin{array}{l}\text { 1.3. Are the } \\
\text { findings } \\
\text { adequately } \\
\text { derived from the } \\
\text { data? }\end{array}$ & $\begin{array}{l}\text { 1.4. Is the } \\
\text { interpretation of } \\
\text { results } \\
\text { sufficiently } \\
\text { substantiated by } \\
\text { data? }\end{array}$ & $\begin{array}{l}\text { 1.5. Is there } \\
\text { coherence between } \\
\text { qualitative data } \\
\text { sources, collection, } \\
\text { analysis and } \\
\text { interpretation? }\end{array}$ \\
\hline $\begin{array}{l}\text { Austin et al., } \\
2005\end{array}$ & Yes & Yes & Yes & Yes & No & Yes & Yes \\
\hline $\begin{array}{l}\text { Butterworth } \\
\text { et al., } 2017\end{array}$ & Yes & Yes & Yes & Yes & Yes & Yes & Yes \\
\hline $\begin{array}{l}\text { Hazen et al., } \\
2018 \text { a }\end{array}$ & Yes & Yes & Yes & Yes & Yes & Yes & Yes \\
\hline $\begin{array}{l}\text { Hazen et al., } \\
2018 b\end{array}$ & No & - & - & - & - & - & - \\
\hline $\begin{array}{l}\text { Sadler et al., } \\
2014\end{array}$ & Yes & Yes & Yes & Yes & Yes & Yes & Yes \\
\hline $\begin{array}{l}\text { Quantitative } \\
\text { descriptive } \\
\text { studies }\end{array}$ & $\begin{array}{l}\text { S1. Are } \\
\text { there clear } \\
\text { research } \\
\text { questions? }\end{array}$ & $\begin{array}{l}\text { S2. Do the } \\
\text { collected } \\
\text { data address } \\
\text { the research } \\
\text { questions? }\end{array}$ & $\begin{array}{l}\text { 4.1. Is the sampling } \\
\text { strategy relevant to } \\
\text { address the } \\
\text { research question? }\end{array}$ & $\begin{array}{l}\text { 4.2. Is the sample } \\
\text { representative of } \\
\text { the target } \\
\text { population? }\end{array}$ & $\begin{array}{l}\text { 4.3. Are the } \\
\text { measurements } \\
\text { appropriate? }\end{array}$ & $\begin{array}{l}\text { 4.4. Is the risk of } \\
\text { non-response } \\
\text { bias low? }\end{array}$ & $\begin{array}{l}\text { 4.5. Is the statistical } \\
\text { analysis appropriate } \\
\text { to answer the } \\
\text { research question? }\end{array}$ \\
\hline $\begin{array}{l}\text { Jesson, Wilson } \\
\text { \& Blenkinsopp, } \\
2001\end{array}$ & Yes & Yes & Yes & Yes & Yes & No & Yes \\
\hline $\begin{array}{l}\text { Lau, Dolovich, \& } \\
\text { Austin, } 2007\end{array}$ & Yes & Yes & Yes & Yes & Yes & Yes & Yes \\
\hline
\end{tabular}


Table III outlines quality analysis of each study included in the review. One did not pass the screening question (Hazen et al., 2018b), one had a risk of self-reporting bias (Jesson, Wilson, \& Blenkinsopp, 2001), and one did not describe how the data analysis was utilised, so it was therefore difficult to interpret if the findings of the study derived from the data (Butterworth et al., 2017).

Studies that described an educational programme undertaken by pharmacists took place in one or more of the following settings: simulated family practice (Austin et al., 2005), face-to-face classroom lessons at an associated university or GP practice (Sadler et al., 2014; Butterworth et al., 2017; Hazen et al., 2018b), at home self-directed learning (Austin et al., 2005), an optional one-day placement in general practice (Butterworth et al., 2017), and workplace learning (Hazen et al., 2018b). Contact time varied across all programmes from a two-day weekend workshop (Austin et al., 2005), six full days (Butterworth et al., 2017), 46 training days over 15 months (Hazen et al., 2018b) and 22 hours over five days (Sadler et al., 2014). From the studies that covered specific therapeutic areas, these included: asthma, hypertension, diabetes, osteoporosis (Austin et al., 2005; Butterworth et al., 2017), hyperlipidaemia (Austin et al., 2005), ears, nose and throat, common dermatological conditions, eye symptoms, respiratory infections, and rheumatoid arthritis (Butterworth et al., 2017).

The educational content varied across studies with examples depicted in Table IV. Assessments used to evaluate pharmacists' knowledge after the training programmes included written examinations (Jesson, Wilson, \& Blenkinsopp, 2001; Butterworth et al., 2017; Hazen et al., 2018b), oral examinations (Jesson, Wilson, \& Blenkinsopp, 2001; Butterworth et al., 2017), coursework (Hazen et al., 2018b), and objective structured clinical examinations (OSCE) (Lau, Dolovich, \& Austin, 2007).

From the studies that reviewed participant perceptions of the education training that were undertaken, a number of efficacious aspects were identified. These included receiving feedback from GPs (Jesson, Wilson, \& Blenkinsopp, 2001; Sadler et al., 2014 Butterworth et al., 2017), the applicability of training to traditional pharmacy settings (Austin et al., 2005; Sadler et al., 2014), having the opportunity to network with other pharmacists and health professionals working in primary care (Jesson, Wilson, \& Blenkinsopp, 2001; Butterworth et al., 2017; Hazen et al., 2018a), using role-play to consolidate learned skills before putting them in to practice (Jesson, Wilson, \& Blenkinsopp, 2001; Sadler et al., 2014; Hazen et al., 2018a) and focusing on specific disease states (Austin et al., 2005).
Table IV: Examples of educational content in studies

\begin{tabular}{l|l}
\hline Education content & Study \\
\hline $\begin{array}{l}\text { Communication: patient } \\
\text { interviewing, pharmacist } \\
\text { interaction with GPs and other } \\
\text { health care providers }\end{array}$ & $\begin{array}{l}\text { Austin et al., 2005 } \\
\text { Hazen et al., 2018a }\end{array}$ \\
\hline $\begin{array}{l}\text { Education: patient education, } \\
\text { drug information question and } \\
\text { answer, educating GPs and } \\
\text { other members of the health } \\
\text { care team on pharmacotherapy, } 2001\end{array}$ & Hustin et al., 2005 \\
\hline $\begin{array}{l}\text { Medication assessment: } \\
\text { identification of drug therapy } \\
\text { problems, developing } \\
\text { pharmaceutical care plans, } \\
\text { medicines management and } \\
\text { optimisation }\end{array}$ & Butterworth et al., 2017 \\
\hline $\begin{array}{l}\text { Evidence-based practice } \\
\text { delivery of general practice }\end{array}$ & Butterworth et al., 2017; \\
\hline $\begin{array}{l}\text { UK Prescribing analysis and cost } \\
\text { tabulation (PACT) assimilation }\end{array}$ & Jesson, Wilson, \& Blenkinsopp, 2001 \\
\hline $\begin{array}{l}\text { Root cause analysis (RCA) } \\
\text { management }\end{array}$ & Butterworth et al., 2017; \\
\hline $\begin{array}{l}\text { Patient monitoring and } \\
\text { follow-up }\end{array}$ & Jesson, Wilson, \& Blenkinsopp, 2001 \\
\hline $\begin{array}{l}\text { Documentation } \\
\text { Interpretation of blood results }\end{array}$ & Butterworth et al., 2017 \\
\hline
\end{tabular}

Significant associated costs were perceived as a barrier for the implementation of education and training programmes not only for the participants' themselves, but for companies delivering these programmes (Jesson, Wilson, \& Blenkinsopp, 2001; Austin et al., 2005). Other barriers included the lack of available courses related to enhancing skills for use in primary care, difficulty in balancing studying, work and family commitments and some found the courses stressful due to logistics and duration (Jesson, Wilson, \& Blenkinsopp, 2001; Butterworth et al., 2017).

One study looked at the perceptions of content of future training courses (Jesson, Wilson, \& Blenkinsopp, 2001). More than half the respondents highlighted possible inclusions for enhanced future training courses to involve training related to the prescribing analysis and cost tabulation (PACT)/cost control systems, rational choice of drugs, therapeutic knowledge updates, communication/ interpersonal skills, effective management of repeat prescriptions, and medication review techniques (Lau, Dolovich, \& Austin, 2007). 


\section{Discussion}

This is the first systematic review globally exploring the availability of post graduate education directed at pharmacists wishing to utilise their skills in general practice. Previous systematic reviews have considered the services provided and impact on health outcomes of pharmacists integrated within general practice (Tan et al., 2014, Hazen et al., 2018c). A recent review conducted in Australia has developed a role description and a global competency map for GP pharmacists (Benson, et al., 2019b). Recommendations from this study acknowledge that further studies are required to establish the educational needs of GP pharmacists which can then inform evidence-based educational programmes to further develop the skills and knowledge required for this role. This review provides a summary of published education currently available and being practiced globally to help further inform competency-based education.

Increasing pharmaceutical services that are general practice based have been noted internationally since 2002 (Fish, Watson, \& Bond, 2002). Despite the establishment of such services over the last 15 years, there is limited availability of published research regarding education and training that is available for these pharmacists entering into this evolving scope of practice. This review has identified a number of areas that are targeted by providers and being taught to extend upon pharmacists' knowledge and skills entering into this field of practice. Working with GP systems (Sadler et al., 2014), documentation (Austin et al., 2005), medication assessment (Butterworth et al., 2017; Hazen et al., 2018b), clinicianpatient communication (Hazen et al., 2018b), communication with other practice staff (Austin et al., 2005; Jesson, Wilson, \& Blenkinsopp, 2001), and educating GPs and patients (Austin et al., 2005; Hazen et al., 2018b) are just some of the areas of focus of these training programmes. The attainment of these skills is supported by the study performed by Farrell et al. which examined the experiences of pharmacists in Ontario, Canada being integrated into family practice settings (Farrell et al., 2008). It found that there were a number of skills pharmacists were lacking which included completing and documenting efficient and effective comprehensive medication assessments; accepting clinical uncertainty; dealing with complex patient situations; interpreting lab results; focusing on and prioritising problems in assessments; and written communication skills (Farrell et al., 2008).

Role-play and general practice simulations were perceived by participants to be the most beneficial modes for learning. The practise of inter-professional communication was of particular value prior to taking post as a practice pharmacist (Austin et al., 2005; Sadler et al., 2014). For example, with regards to training in root cause analysis, one pharmacist recalled role-play being daunting but 'was probably the most useful part of the training' (Sadler et al., 2014). Similarly, role-play and patient-simulation have previously been shown to be useful amongst undergraduate pharmacy students to develop patient-care skills and improving confidence in communication and information gathering (James et al., 2001; Rao, 2011).

Content delivery by pharmacists and other healthcare professionals who work in primary care and acted as role models was of particular value and significance for students (Jesson, Wilson, \& Blenkinsopp, 2001; Austin et al., 2005; Butterworth et al., 2017). Less experienced participants valued the opportunity to network with pharmacists who were already working in primary care, enabling them to put the training into context and to visualise the potential of their future role, in addition to the healthcare workers' ability to offer valid and relevant feedback on the pharmacists performance (Jesson, Wilson, \& Blenkinsopp, 2001; Butterworth et al., 2017). It was also noted that pharmacists valued the family practice simulator training programme focusing on specific disease states such as asthma, hypertension, diabetes, osteoporosis and hyperlipidaemia (Austin et al., 2005). The management of these chronic conditions has been shown to improve with pharmacist services provided in general practice (Tan et al., 2014; Anderson et al., 2019).

Butterworth et al. included both pharmacists already working in primary care and those without experience. Experienced primary care pharmacists found the course undertaken as part of the study had very little impact on their attitudes towards their current roles and practices (Butterworth et al., 2017). However, it was recognised that pharmacists should have a formal, standardised qualification in primary care, but there were significant differences in the level of agreement of this accreditation procedure between respondents who had undertaken formal education or training compared with those who had not (Jesson, Wilson, \& Blenkinsopp, 2001; Butterworth et al., 2017). There was a desire for longer, more structured and systematic debriefing sessions at the cessation of training courses (Austin et al., 2005; Lau, Dolovich, \& Austin, 2007). It was also suggested that more opportunities for hands-on experience with GP clinical systems should be included as part of the training process and would benefit those pharmacists unfamiliar with these systems. However, developing a generic training module to cover all GP computer programmes may prove difficult due to the varying nature of IT equipment (Jesson, Wilson, \& Blenkinsopp, 2001; Sadler et al., 2014). 
None of the educational programmes resulted in a formal qualification, however many included assessments such as coursework, written examinations, and oral examinations (Jesson, Wilson, \& Blenkinsopp, 2001; Butterworth et al., 2017; Hazen et al., 2018b). One study developed an OSCE using a 5-point Global Rating Scale (GRS) to assess the pharmacists' overall performance and their performance in four process-related domains (Lau, Dolovich, \& Austin, 2007). These domains related to verbal communication; non-verbal communication; ability to respond to the agent's feelings and needs, and degree of focus; logic and coherence. Checklists were used in conjunction to assess if pharmacists had covered the relevant content to meet the five objectives of each station which included making appropriate drug therapy recommendations, recommending appropriate follow-up and monitoring and providing patients with education on appropriate use of medications.

While it has been acknowledged pharmacists need to further develop their skill set through continuing education, it is difficult to create training and education without a definitive list of competencies and a set role description. The FIP Education Initiatives (FIPEd) 'advocates for the use of needs-based education and training strategies where pharmacy education provision is socially accountable, practice and science are evidencebased and practitioners have the required competencies to provide needs-based services to their communities' (FIP, 2012b). An Australian and Canadian study has developed a set of competencies based on the role of pharmacists working in primary care in their respective countries (Kennie-Kaulbach et al., 2012; Benson et al., 2019b). These competencies revolve around communication, professionalism, care provision, medication management, patient examination and screening, chronic disease management, drug information and education, collaboration and liaison, audit and quality assurance, and research. While most of the training programmes incorporated these elements, only one of the included studies developed learning objectives built on a competencybased framework which was discussed with a group of pharmacy practitioners experienced in pharmacy teaching and education development (Jesson, Wilson, \& Blenkinsopp, 2001). This suggests that the training programmes that have been developed may be incorporating unnecessary elements or may not be meeting the needs of pharmacists undertaking them.

Despite the large encompassing scope of the search, only a small number of articles met the inclusion/exclusion criteria highlighting the paucity of literature on this subject matter making it difficult to generalise the findings of this study. Of those published, only small numbers of participants were included. However, the methodological rigour of most of the studies included were of sound quality having met all the criteria of the MMAT quality analysis tool. There were methodological limitations identified in some studies which included a lack of clear research question, self-reporting bias, and findings not adequately derived from the data. Moreover, as this review included studies of various designs, this limited ability for direct comparison. Additionally, the number of countries the studies were conducted in was small. Pharmacy education, qualification and practice differs worldwide, and it is thereby difficult to generalise studies across countries. While there may be some similarities in primary care and the education pharmacists may require helping integrate as part of a general practice team, this must be considered with caution. For instance, in the USA the six-year Pharm.D. graduate or trainee in family medicine exists and equips pharmacists to work as part of a general practice team upon graduation (Marrs, 2006). Any education or training programmes in this context were excluded as part of the search strategy as it is not possible to separate the training specific to general practice and thereby no studies from the USA were included.

While a number of studies acknowledge the requirement for further training and skill acquisition for pharmacists entering into this role, the development and evaluation of such training programmes appears to be lacking as evidenced by the paucity of published literature. This review highlights the necessity for pharmacy practice educators to develop educational programmes or accredited qualification requirements in order to help further develop and establish the role of pharmacists in general practice. These accreditations should be grounded on educational needs and learning objectives developed from a given set of competencies and role requirements.

\section{Conclusion}

While education and training for pharmacists wishing to enter the general practice setting is deemed necessary, there is a paucity of published research in relation to the development and evaluation of this education. The available literature highlights that a combination of work and classroom-based education provided by GPs and pharmacists already working in primary care is deemed as most beneficial in providing pharmacists an opportunity to place theory learnt in the classroom into context. The 
results of this study suggest future training should concentrate on specific disease states, communication, collaboration and liaison, medication management, patient examination, care provision, drug information and education, coupled with systematic debriefing sessions at the cessation of the training course. Further studies are required to establish competency-based education programmes that are country specific for pharmacists entering into general practice.

\section{Contributors}

The lead author would like to thank librarian Susan Young at the University of Nottingham for her support and research expertise during the development of the search strategy.

\section{References}

American Society of Health-System Pharmacists. (1999). ASHP statement on the pharmacist's role in primary care. American Journal of Health-System Pharmacy, 51(16), 1665-1667. https://doi.org/10.1093/ajhp/56.16.1665

Anderson, C., Zhan, K., Boyd, M., \& Mann, C. (2019). The role of pharmacists in general practice; A realist review. Research in Social \& Administrative Pharmacy, 15(4), 338-345. https://doi.org/ $\underline{10.1016 / \text { i.sapharm.2018.06.001 }}$

Austin, Z., Dolovich, L., Lau, E., Tabak, D., Sellors, C., Marini, A., \& Kennie, N. (2005). Teaching and assessing primary care skills: the family practice simulator model. American Journal of Pharmacy Education, 69(4), Art. 68. https://doi.org/10.5688/aj690468

Benson, H., Lucas, C., Benrimoj, S.I., \& Williams, K.A. (2019). The development of a role description and competency map for pharmacists in an interprofessional care setting. International Journal of Clinical Pharmacy, 41(2), 391-407. https://doi.org/ 10.1007/s11096-019-00808-4

Benson, H., Lucas, C., Kmet, W., Benrimoj, S.I., \& Williams, K. (2018). Pharmacists in general practice: a focus on drug-related problems. International Journal of Clinical Pharmacy, 40(3), 566-572. https://doi.org/10.1007/s11096-018-0617-9

Bruno, A., Bates, I., Brock, T., \& Anderson, C. (2010). Towards a Global Competency Framework. American Journal of Pharmacy Education, 74, 56. https://doi.org/10.5688/aj740356

Bush, J., Langley, C.A., Jenkins, D., Johal, J., \& Huckerby, C. (2018). Clinical pharmacists in general practice: an initial evaluation of activity in one English primary care organisation. International Journal of Pharmacy Practice, 26(6), 501-506. https://doi.org/ 10.1111/ijpp.12426

Butterworth, J., Sansom, A., Sims, L., Healey, M., Kingsland, E., \& Campbell, J. (2017). Pharmacists' perceptions of their emerging general practice roles in UK primary care: a qualitative interview study. British Journal of General Practice, 67(662), e650-e658. https://doi.org/10.3399/bigp17X691733
Choe, H.M., Farris, K.B., Stevenson, J.G., Townsend, K., Diez, H.L., Remington, T.L., Rockafellow, S., Shimp, L.A., Sy, A., Wells, T., \& Standiford, C.J. (2012). Patient-centered medical home: developing, expanding, and sustaining a role for pharmacists. American Journal of Health-System Pharmacy, 69(12), 1063-1071. https://doi.org/10.2146/ajhp110470

Dolovich, L., Pottie, K., Kaczorowski, J., Farrell, B., Austin, Z., Rodriguez, C., Gaebel, K., \& Sellors, C. (2008). Integrating family medicine and pharmacy to advance primary care therapeutics. Clinical Pharmacology and Therapeutics, 83(6), 913-917. https://doi.org/10.1038/clpt.2008.29

Farrell, B., Pottie, K., Haydt, S., Kennie, N., Sellors, C., \& Dolovich, L. (2008). Integrating into family practice: the experiences of pharmacists in Ontario, Canada. International Journal of Pharmacy Practice, 16(5), 309-315. https://doi.org/10.1211/ijpp.16.5.0006

Fish, A., Watson, M., \& Bond, C. (2002). Practice-based pharmaceutical services: a systematic review. International Journal of Pharmacy Practice, 10(4), 225-33. https://doi.org/10. $\underline{1211 / 096176702776868451}$

Freeman, C., Cottrell, N., Rigby, D., William, I.D., \& Nissen, L. (2014). The Australian practice pharmacist. Journal of Pharmacy Practice and Research,44(4), 240-248. https://doi.org/10.1002/ippr.1027

Global Knowledge Exchange Network. (2009). An overview of education and training requirements for global healthcare professionals: Pharmacist. Available at: http://gken.org/Docs/ Workforce/Pharmacy\%20Education\%20FINAL\%20102609.pdf

Hazen, A.C.M., de Bont, A.A., Boelman, L., Zwart, D.L.M., de Gier, J.J., de Wit, N.J., \& Bouvy, M.L. (2018). The degree of integration of non-dispensing pharmacists in primary care practice and the impact on health outcomes: A systematic review. Research in Social \& Administrative Pharmacy, 14(3), 228-240. https://doi.org/ 10.1016/i.sapharm.2017.04.014

Hazen, A.C.M., de Groot, E., de Bont, A.A., de Vocht, S., de Gier, J.J., Bouvy, M.L., de Wit, N.J., \& Zwart, D.L.M. (2018a). Learning through boundary crossing: professional identity formation of pharmacists transitioning to general practice in the Netherlands. Academic Medicine, 93(10), 1531-1538. https://doi.org/10.1097/ ACM. 0000000000002180

Hazen. A., de Groot, E., de Gier, H., Damoiseaux, R., Zwart, D., \& Leendertse, A. (2018). Design of a 15-month interprofessional workplace learning program to expand the added value of clinical pharmacists in primary care. Currents in Pharmacy Teaching and Learning, 10(5), 618-626. https://doi.org/10.1016/i.cptl.2018.01.006

Hong, Q.N., Pluye, P., Fàbregues, S., Bartlett, G., Boardman, F., Cargo, M., Dagenais, P., Gagnon, M.P., Griffiths, F., Nicolau, B., O'Cathain, A., Rousseau, M.C., \& Vedel, I. (2018). Mixed Methods Appraisal Tool (MMAT), version 2018. Registration of Copywright (\#1148552). Canadian Intellectual Property Office, Industry Canada

FIP [International Pharmaceutical Federation]. (2009). FIP Global Pharmacy Workforce Report. International Pharmaceutical Federation (FIP). Available at: https://www.fip.org/files/fip/ publications/2009 FIP Global Pharmacy Workforce Report.pdf FIP [International Pharmaceutical Federation]. (2012a). Global competency framework (GbCF v1) for services provided by pharmacy workforce. Available at: https://www.fip.org/files/fip/ PharmacyEducation/GbCF v1.pdf 
FIP [International Pharmaceutical Federation]. (2012b). FIP Global Pharmacy: Workforce Report. International Pharmaceutical Federation. Available at: https://www.fip.org/files/members/ library/FIP_workforce_Report_2012.pdf

FIP [International Pharmaceutical Federation]. (2015). Advanced Practice and Specialisation in Pharmacy: Global Report 2015. International Pharmaceutical Federation (FIP). Available at: https://www. fip.org/files/fip/PharmacyEducation/Adv and Spec Survey/FIPEd Advanced 2015 web v2.pdf

James, D., Nastasic, S., Davies, J.G., \& Horne, R. (2001). The design and evaluation of a simulated-patient teaching programme to develop the consultations skills of undergraduate pharmacy students. Pharmacy World \& Science, 23(6), 212-216. https://doi.org/10.1023/A:1014512323758

Jesson, J.K., Wilson, K.A., \& Blenkinsopp, A. (2001). The training experience of primary care pharmacists. International Journal of Pharmacy Practice, 9(2), 119-126. https://doi.org/10.1111/ i.2042-7174.2001.tb01039.x

Kennie-Kaulbach, N., Farrell, B., Ward, N., Johnston, S., Gubbels, A., Eguale, T., Dolovich, L., Jorgenson, D., Waite, N., \& Winslade, N. (2012). Pharmacist provision of primary health care: a modified Delphi validation of pharmacists' competencies. BMC Family Practice, 13(27). https://doi.org/10.1186/1471-2296-13-27

Komwong, D., Greenfield, G., Zaman, H., Majeed, A., \& Hayhoe, B. (2018). Clinical pharmacists in primary care: A safe solution to the workforce crisis? Journal of the Royal Society of Medicine, 111(4), 120-124. https://doi.org/10.1177/0141076818756618

Kozminski, M., Busby, R., McGivney, M.S., Klatt, P.M., Hackett, S.R., \& Merenstein, J.H. (2011). Pharmacist integration into the medical home: qualitative analysis. Journal of the American Pharmacists Association, 51(2), 173-183. https://doi.org/10.1331/JAPhA.2011. $\underline{10188}$

Lau, E., Dolovich, L., \& Austin, Z. (2007). Comparison of self, physician, and simulated patient ratings of pharmacist performance in a family practice simulator. Journal of Interprofessional Care, 21(2), 129-140. https://doi.org/10.1080/ $\underline{13561820601133981}$

Mann, C., Anderson, C., Avery, A.J., Waring, J., \& Boyd, M.J. (2018). National evaluation of clinical pharmacists in GP practices; pilot phase. University of Nottingham. Available at: https://www.notting ham.ac.uk/pharmacy/documents/generalpracticeyearfwdrev/clini cal-pharmacists-in-general-practice-pilot-scheme-full-report.pdf

Marrs, J.C. (2006). Family medicine pharmacy residency programs. American Journal of Health-System Pharmacy, 63(19), 1803-1805. https://doi.org/10.2146/ajhp060201

Mills, E. (2018). A training needs analysis of clinical pharmacists in general practice. NHS Health Education England. Available at: https://www.lasepharmacy.hee.nhs.uk/dyn/ assets/ folder4/co mmunity-pharmacy/pharmacists-in-gp/TrainingNeedsofClinicalPh armacistsinGeneralPracticeFINAL.pdf

Moher, D., Liberati, A., Tetzlaff, J., Altman, D.G., \& PRISMA Group. Preferred reporting items for systematic reviews and meta-analysis: the PRISMA statement. (2009). Annals of Internal Medicine, 151(4), 264-269. https://doi.org/10.7326/0003-4819151-4-200908180-00135
Mossialos, E., Courtin, E., Naci, H., Benrimoj, S., Bouvy, M., Farris, K., Noyce, P., \& Sketris, I. (2015). From "retailers" to health care providers: transforming the role of community pharmacists in chronic disease management. Health Policy, 119(5), 628-639. https://doi.org/10.1016/i.healthpol.2015.02.007

Nash, R.E., Chalmers, L., Brown, N., Jackson, S., \& Peterson, G. (2015). An international review of the use of competency standards in undergraduate pharmacy education. Pharmacy Education, 15(1), 131-141

Pace, R., Pluye, P., Bartlett, G., Macaulay, A.C., Salsberg, J., Jagosh, J., \& Seller, R. (2012). Testing the reliability and efficiency of the pilot Mixed Methods Appraisal Tool (MMAT) for systematic mixed studies review. International Journal of Nursing Studies, 49(1), 47-53. https://doi.org/10.1016/j.ijnurstu.2011.07.002

Pluye, P., Gagnon, M.P., Griffiths, F., \& Johnson-Lafleur, J. (2009). A scoring system for appraising mixed methods research, and concomitantly appraising qualitative, quantitative and mixed methods primary studies in mixed studies reviews. International Journal of Nursing Studies, 46(4), 529-546. https://doi.org/10. 1016/j.ijnurstu.2009.01.009

Popay, J., Roberts, H., Sowden, A., Petticrew, M., Arai, L., Rodgers, M., Britten, N., Roen, K., \& Duffy, S. (2006). Guidance on the conduct of narrative synthesis in systematic reviews: A product from the ESRC methods programme. University of Lancaster. https://doi.org/10.13140/2.1.10184643

Rao, D. (2011). Skills development using role-play in a first-year pharmacy practice course. American Journal of Pharmacy Education, 75(5), Art.84. https://doi.org/10.5688/ajpe75584

Sadler, S., Rodgers, S., Howard, R., Morris, C.J., Avery, A.J., \& PINCER Triallists. (2014). Training pharmacists to deliver a complex information technology intervention (PINCER) using the principles of educational outreach and root cause analysis. International Journal of Pharmacy Practice, 22(1), 47-58. https://doi.org/10. 1111/ijpp.12032

Saseen, J.J., Ripley, T.L., Bondi, D., Burke, J.M., Cohen, L.J., McBane, S., McConnell, K.J., Sackey, B., Sanoski, C., Simonyan, A., Taylor, J., \& Vande Griend, P. (2017). ACCP clinical pharmacist competencies. Pharmacotherapy, 37(5), 650-636. https://doi.org/ $\underline{10.1002 / \text { phar.1923 }}$

Sellors, C., Dalby, D., Howard, M., Kaczorowski, J., \& Sellors, J. (2001). A pharmacist consultation service in community-based family practices: A randomized, controlled trial in seniors. Journal of Pharmacy Technology, 17(6), 264-269. https://doi.org/10.1177/ $\underline{875512250101700604}$

Silcock, J., Raynor, D.K.T, \& Petty, D. (2004). The organisation and development of primary care pharmacy in the United Kingdom. Health Policy, 67(2), 207-214. https://doi.org/10.1016/S01688510(03)00121-0

Souto, R.Q., Khanassov, V., Hong, Q.N., Bush, P.L., Vedel, I., \& Pluye, P. (2015). Systematic mixed studies reviews: updating results on the reliability and efficiency of the Mixed Methods Appraisal Tool. International Journal of Nursing Studies, 52(1). https://doi.org/10.1016/i.jinurstu.2014.08.010 
Stone, M.C., \& William, H.C. (2015). Clinical pharmacists in general practice: value for patients and the practice of a new role. British Journal of General Practice, 65(634), 262-263. https://doi.org/ $\underline{10.3399 / \text { bjgp15X685033 }}$

Tan, E.C., Stewart, K., Elliot, R.A., \& George, J. (2014). Pharmacist consultations in general practice clinics: The Pharmacists in Practice Study (PIPS). Research in Social and Administrative Pharmacy, 10(4), 623-632.https://doi.org/10.1016/i.sapharm. $\underline{2013.08 .005}$

Tan, E.C., Stewart, K., Elliot, R.A., \& George, J. (2014). Pharmacist services provided in general practice clinics: a systematic review and meta-analysis. Research in Social \& Administrative Pharmacy, 10(4), 608-622. https://doi.org/10.1016/i.sapharm.2013.08.006 